\title{
Cheilitis glandularis
}

INSERM

\section{Source}

INSERM. (1999). Orphanet: an online rare disease and orphan drug data base. Cheilitis glandularis. ORPHA:1221

Cheilitis glandularis (CG) is an uncommon chronic inflammatory disease of unknown orig in characterized by macrocheilia and secretions of thick saliva from swollen labial minor salivary glands. 